\title{
A Different Approach to Sustainable Architecture Based on the Sense of Place
}

\author{
Jamaleddin Honarvar ${ }^{1}$
}

\begin{abstract}
:
This study addressed other dimensions of sustainable architecture. Sustainable architecture is generally related to energy management, technology, climate, and relevant subjects; whereas, the principal notion of it is related to the sense of place, psychological values of its dwellers, ontological matters, contextualize, compatibility with municipal bodies, spirituality, economic issues, and identification. It is a qualitative study with a descriptive-analytical design. Results indicate that paying attention to the creation of the sense of place, human identity, and ontological matters are effective in the development of sustainable architecture

Keywords: Sustainable Architecture, Sense of Place, Psychological Values, Ontology, Spirituality
\end{abstract}

1. Master of Architecture, Phone number: 00989121033150, Email: honarvar.arch@gmail.com 
$9^{\text {th }}$ International Conference on Research in

Engineering, Science and Technology

France | Paris | April 19-21, 2019

\section{Introduction:}

This study has first addressed the principles of sustainable architecture including the understanding of the sense of place, the nature of being and not-interfering in it, psychological values of dwellers, dissolution in urban fabric, compatibility with municipal bodies, etc. Then, it has specifically investigated the sense of place and its relationship with sustainable architecture.

Regarding that the sense of place is affected by the quality of space and design mechanism, this study has aimed to get more familiar with this concept and also to specify its causing factors to come up with a better design. Although several meanings have been attached to the place and space, the distinctive characteristic of space, taken into account in this article, is its greater specificity than space and also its integration with human values. On the other hand, the defining abstract and objective characteristics of space have made it distinct from place. The poets and scholars have been inspired by place character and used those inspirations to describe life and events.

According to these descriptions, the sense of place is a collection of individual and collective stories and narratives that happen along with the place. In addition, the sense of place has been defined and studied from phenomenological and scientific perspectives. The study of this concept from different perspectives makes the meaning of this sense more clear.

\section{Theoretical Principles:}

\subsection{Sustainable Development}

Sustainable development defined as social, economic and environmental development.Design and skills trainings are main part of social development should be matched with social values and environmental resources. (Hosseini, 2008)

Sustainable development refers to a wide idea and term with many different meanings that resulting to rise various reactions of experts. The concept of sustainable development refers to attempt for combination the contexts. Therefore, humanity is able to develop sustainability in order to provide recent requirements with no problems for the ability of future generations to meet their needs, according to Brundtland (Hosseini, 2008).

Some others such as Alen Friker presented sustainability as a vision to future focused on a series of moral and spiritual values and principles controlling human behaviors (Gorji Mahlabani, 2010).

\subsection{Sustainable architecture}


It is essential to search some strategies in order to deal with existing unfavorable status and to improve undesired results of intervention in body of urban, so that sustainable urban development will be provided [3].

Better perception of sustainable architecture requires for clear definition of sustainable development. Although, experts have a consensus on "policies and plans that lead to sustainable development should be used as a solution for global problem", their opinions are different in definition of sustainable development. So, there are various definitions for the context of sustainable development. But this context may involve ambiguity and use incorrectly. Correct definition reported by Brundtland; sustainable development is a development to meet new generation needs without of reconciliation and regardless future generation to provide their requirements (Golkar, 2000). Finally, it must note that sustainable development involves a comprehensive context including all aspects of human life. Some researches such as novel studies done by Golan in the field of sustainable architecture indicated that the architecture of Middle East old cities are matched with their environmental features considerably (Golan, 1995).

Some researchers such as Giovanni believed that the main goal of urban architecture and design regarding climate is " low rate of stress affects on individuals derived from climate" (Mahmoudi, 2011).

Use of the contexts of sustainability and goals of sustainable development in order to reduce energy wasting and environment pollution in architecture created an issue called "sustainable architecture". With this architecture, building not only is incompatible with its region climate status, it establishes a mutual relationship with that. So that, buildings are like birds that puff their feathers in winter in compatible with new environment status and adjusted their metabolism with that. Also, sustainable architecture help to reduce the consumption of energy natural resources regarding to the compatibility between building and climate, to use renewable energy sources in the building, to reduce changes in land, to match with site, to use environmental factors to provide comfort and relaxation in building and use of recyclable materials, to protect nature, and to decline toxin in nature. An architect of BC centuries, Vitruvius, presented three stability principles include building strength against natural and unnatural factors and persistence of materials, and finally sustainability of building in human minds and also identified maintaining the efficiency of building in different conditions and times. (Pakzad, 2007)

\subsection{Sustainable architecture aims}

Give importance human life and maintain that in present and future, apply materials in compatible with environment either during production or usage and even destroy, reduce fuel energies consumption, increase natural energies consumption, decrease environmental destruction, improve human and all creatures life physically and mentally and match with natural environment. In this regard, there are several principles for this architecture as following: 
"Perception of sense of place, existing space without disturbances for that, use of natural energies such as solar, wind,... energies, apply local and natural materials, recyclable and stable, collect and use water especial rain water and utilize lake, sea, etc, insulate thermally, sound and proper for building, capability for natural conditioning through roof, etc, get lighting correctly, design openings accurately (Gorji Mahlabani, 2010).

\subsection{Terminology of sustainable architecture}

Although, theorists and architects studied green, climatic and sustainable architecture, today it presents as sustainable architecture considering energy, climate and optimal fuel consumption without sustainability of thought, meaning, identity, etc. During last forty years, designing environment houses and also buildings in compatible with climate has been considered. But, in this context, the architects achieved success slightly. Architects' efforts are not important much. Aware architects showed their concerns for rejection of the designs by customers using a long list. Although, environment issues should be listed in social plans, there are less attention to climate due to economic necessities. Uncomfortable fact is that a good environmental building may be known as a bad architecture. It is better that the building design the compact and dense within minimum external surface. The word "sustainable" means tolerable and preservative but not stability. Tadao Ando says: "I build buildings that are tolerable in nature and somehow can tolerate against intact nature. Otherwise, each person knows that it is impossible to exchange the nature with any artificial phenomenon. Sustainable architecture in the sense of maintenance should be maintained the identity and matched the reality with mental images during historical layers now and in the future and also it should be tolerable in nature as well as stable, simulated and similar nature (Panahi, 2007).

Tadao Ando created Prayer Niche (Mihrab) space with nature putting a cross in the pool. Mihrab, first adorned by Vitra in Gothic churches. Now, Ando adorned Mihrab with nature and dynamically. Mihrab changed in compatible with different seasons in spring, summer, fall and winter and also is snowy for 5 month showed sad environment. A cross that should be sad with Jesus Statue. Ando put a cross to show a sense of place to pool. As noted, principles of sustainable architecture refers to following issues; "perception of sense of place, perception of existing space without disturbances, having identity and belonging to now, green and nature-oriented architecture and its subsets (ecotech, organtech, bionic, biotech, gaia), have context and thought, establish social communication, value during building lifetime, mental value of residents, dissolved in urban tissue, compatible with urban natures, compatible with status and problems and have strength, optimize energy consumptions, use renewable resources, reduce founded energy. (Panahi, 2011)

Above 15 principles should be used for beauty and creating attractive space to show as an art. Today, process of building incorrectly used instead of sustainable architecture. Some of the theorists like McDonough said that sustainable architecture have not aesthetics, they generally say truth. Now, a building that is incompatible with organic and expressionist architecture (two architecture styles ignored by emerging modern architecture in early twenty century) followed correct design environmentally. These two styles use to design Bank NMB around Amsterdam by Anton Alberts and et.al in Netherlands. This building often known 
as greener architecture or lower energy consumer around the world. Inactive solar heating, small windows, chimney effect, central courtyard and mass of building materials used for the building. Here, Five Corners' Fractal Geometry changed, hug mass of building will be broken, but the building still seemed huge and greenest building looks like very ugly typically. So, my manifest is; sustainable architecture should be most beautiful (Panahi, 2011).

According to mentioned subjects regarding to writer's viewpoint, sustainable architecture cannot be defined as each cage or lumpen architecture. Perhaps, sustainable architecture never made considerably, but many works have been done around the world to close its contexts and principles such as architecture of ancient Greece and Rome. Some samples of sustainable architecture that are closer to its contexts and principles showed as following: " Tjibaou, Renzo Piano buildings, Frankfort commercial bank, Norman Foster, Expo2000, Hanover (city in Germany), Thomas Herzog, Japanese stands in expo., Shigeru Ban, Rocco Residential buildings in Japan, Tadao Ando "

Water church by Tadao Ando, Mosque project by Hasan Fathi, Most of projects of site group by James Wines, Works by Ken Yeang and Hamzeh groups, city of Curitiba in Brazil, etc.

There are several examples for those are interesting social responsibilities and build villages in compatible with environment. Also, there are many examples supported by Prince Charls and designed by Doane and Plater Zyberk. Some books are; "Modern Urbanization" , "social architecture", 1994, by Peter Katz and "Next metropolitans of America", " Environment, society and American dream", 1993, by Peter Calthorpe. There are several books in the field of architecture have been wrote by some writers such as Brenda and Robert Wall and James Wines. Also, good buildings made by Zoo group in Japan, Ken Yeang in Malaysia, many of Germany architects such as Gunter Behnisch and many of Americans that build their buildings themselves.

We started 15 principles using sense of place, perception of space and identity and finished to energy in order to present meaning and sustainability of thought. All 15 and most of early principles determined sustainable, preservatives and tolerable architecture for ever (Panahi, 2011).

\subsection{Sense of Place from Phenomenological Perspective}

Phenomenological, the sense of place means connection to place through understanding everyday symbols and activities. This sense can be developed in one's place of living and become deeper and heightened (Relph, 1976).

The individual and collective values affect the mechanism of the sense of place. On the other hand, this sense affects values, attitudes, and specifically individual and social behaviors of people. This is because, people generally get involved with social activities according to the sense of place they feel (Canter, 1971).

The sense of place not only deals with the coordination and appropriate function of human and architectural space, but also addresses the sense of security, pleasure and emotional 
perception. It also strengthens people's identity and their sense of belonging to a place. Phenomenological, the most important concepts implying the sense of place are topophilia, experience of place, and character of place. The sense of place refers to non-material features or character of place with a meaning close to Genius loci (soul or spirit of place). Historically, the spirit of place was associated with holding religious ceremonies and rituals, which required participants to pay close attention to religious practices. In this way, places, where these ceremonies were hosted, automatically became special. This sense of respect was a character of place that distinguished it from other places and was called the spirit of place. The components of this spirit of place were lively and dynamic awareness of environment, religious ritual, and a sense of camaraderie and friendship with place (Brinckerhoff, 1994).

In contemporary interpretations, the sense of place refers to what is created by people in a certain period. It is the results of rituals and repeated events that describe the environment. Some places are such emotionally attractive that leaves an individual with an indescribable feeling, making him/her feel fresh and lively, and interested to return to that place. This is what is called the sense of place.

According to Relf, the sense of place is not a clear concept that can be exactly defined; rather, it should be evaluated through examining the relationships between the place and the bases of geographical phenomenology (Relph, 1976).

According to him, the original meaning of space is something more than its functions, higher than its dwellers, and beyond artificial and worldly experiences of the place. Although all these items are essential aspects of place, but the essence of it lies in experiencing it, i.e. unintentional attention to place, that defines it as a center full of concepts of the world and human existence (Seamon, 1996).

This is the specific quality of insidness that distinguishes places from each other. According to Relf, place is a combination of natural and human-made objects, activities, functions, and meanings, and experience of which can encompass a room to a continent. Insidness can be expressed in physical form, like old cities which were separated from outside space by walls. This experience can be observed in religious ceremonies and rituals that show specific characteristics of a certain place like church or mosque. In such places, experience of religious activities is the main factor in people's sense of place.

In place phenomenology, experience is the most significant foundation of perception. Phenomenological experience means mental purification and understanding the nature of things through manifestation of objects in the individual, which affects the sense of place. Alllen Gussow considers this deep experience as a factor that converts any physical and environmental location into a place. Place is a piece of environment that has been claimed by feelings. This is this feeling that provides us with better understanding of the nature of place. At the deepest levels of human consciousness there is unconsciousness which is associated with place. This is the place that encompasses human roots, and is the center of health, security, and relationship, and finally a point of orientation (Relph, 1976). 
Experience of place is an individual and mental phenomenon, the feeling of which a person shares with many other people. This co-feeling is, in effect, the physical presence of a person in a place and unconscious experience of the place, which is called the "sense of place." The initial level of the sense of place refers to familiarity with place that includes being in a place, regardless of its qualities or meanings. In some people, the experience of place is limited to getting familiar with it, and their relationship with some places is forged only through activities. These people do not pay special attention to place itself, rather they experience a form of place that inhibits them from seeing actual place and participating in its activities. This level of experience of place is seen in people who are under cultural and technological pressures. This is because, they do not have a sense of belonging to the place, rather they geographically have a feeling of alienation (Relph, 1976).

Different levels of familiarity with place include:

1. Deep familiarity with the place: This level is reached when one is physically present in a place (existential insidness). In this state, the person and the place become one.

2. Normal familiarity with place: This refers to unconscious experience of place, which is more collective and cultural than individual. It includes deep participation in symbols of a place, without thinking. This participation is manifested specifically in the experience of religious and familiar places.

3. Superficial familiarity with place: It refers to the experience of a sensitive, but nonfamiliar, person to a place. This person looks to understand the form and meaning of a place according to its dwellers. At this level, the sense of place happens consciously, and it is tried to get involved with the meaning of place without accepting social conventions.

Norberg-Schuls, inspired by the theories of Heidegger on the existence nature of dwelling, relates the task of architecture to dwelling. He believes that dwelling is made when human being adapts himself with environment and identifies himself with it. Dwelling therefore implies something more than shelter. It implies that the spaces where life occurs are places, in the true sense of the word (Hale, 2000).

He also puts that the task of the architecture is to provide physical specifications of place that helps man to dwell. Dwell in the sense of being calmly present in a secure place (Sime, 1986).

Kevin Lynch, like Norberg-Schultz, believes that one dwells when he is capable of objectifying the universe in form of objects and building, which is achieved through architecture. An important task of architecture is objective realization of the sense of place, through which the abstract space is converted into a tangible place and shapes its character.

The character of place is the most important factor of the sense of place. According to Seamon, place not only indicates to a geographical location, but also shows the main character of a site that distinguishes it from other places. In this way, various aspects of a landscape come together to create a distinctive environment and a specific sense of locality (Seamon, 1982). 
According to Norberg-Schultz, place is something more than an abstract space. Environmental character is defined as a totality composed of actual objects and things that have materials, shape, texture, and color (Norberg, 1975), which is, in effect, the nature of place.

Topophilia is a term that is equivalence to the sense of place by phenomenological geographers. Tuan has used this term instead of the sense of place and knows it as an affectionate and affective bond between people and places or settings (Tuan, 2001).

Topophilia is exhibited in different forms such as aesthetic, sensory or emotional. The sense of a place includes a biological reaction to an external physical environment and creation of culture.

\section{Conclusion:}

The general perception obtained from the provided definitions of the sense of place suggests that the sense of place is the product of internal relationship of human, mental imaginations, and environmental properties. On the one hand, this concept has a root in mental experiences such as memory, tradition, history, culture, society, etc. On the other hand, it is affected by objective and external environmental contexts such as layout, landscape, smell, and sound. In conclusion, the sense of place is a complex concept of human feelings and attachment to environment, and is the product of human compatibility to and use of place. 
$9^{\text {th }}$ International Conference on Research in Engineering, Science and Technology

France | Paris | April 19-21, 2019

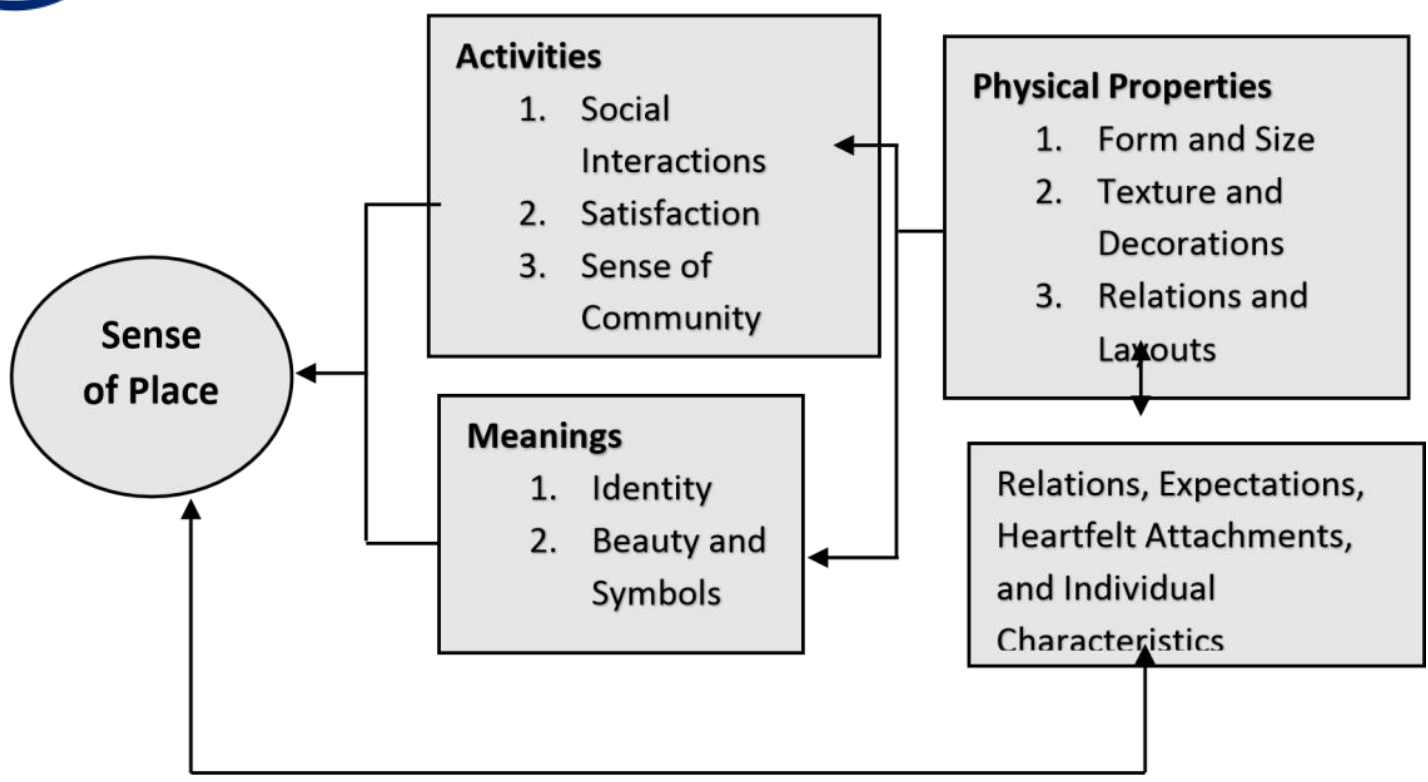

Model 1: Constituent Factors of the Sense of

Place

References: Authors 
$9^{\text {th }}$ International Conference on Research in Engineering, Science and Technology

France | Paris | April 19-21, 2019

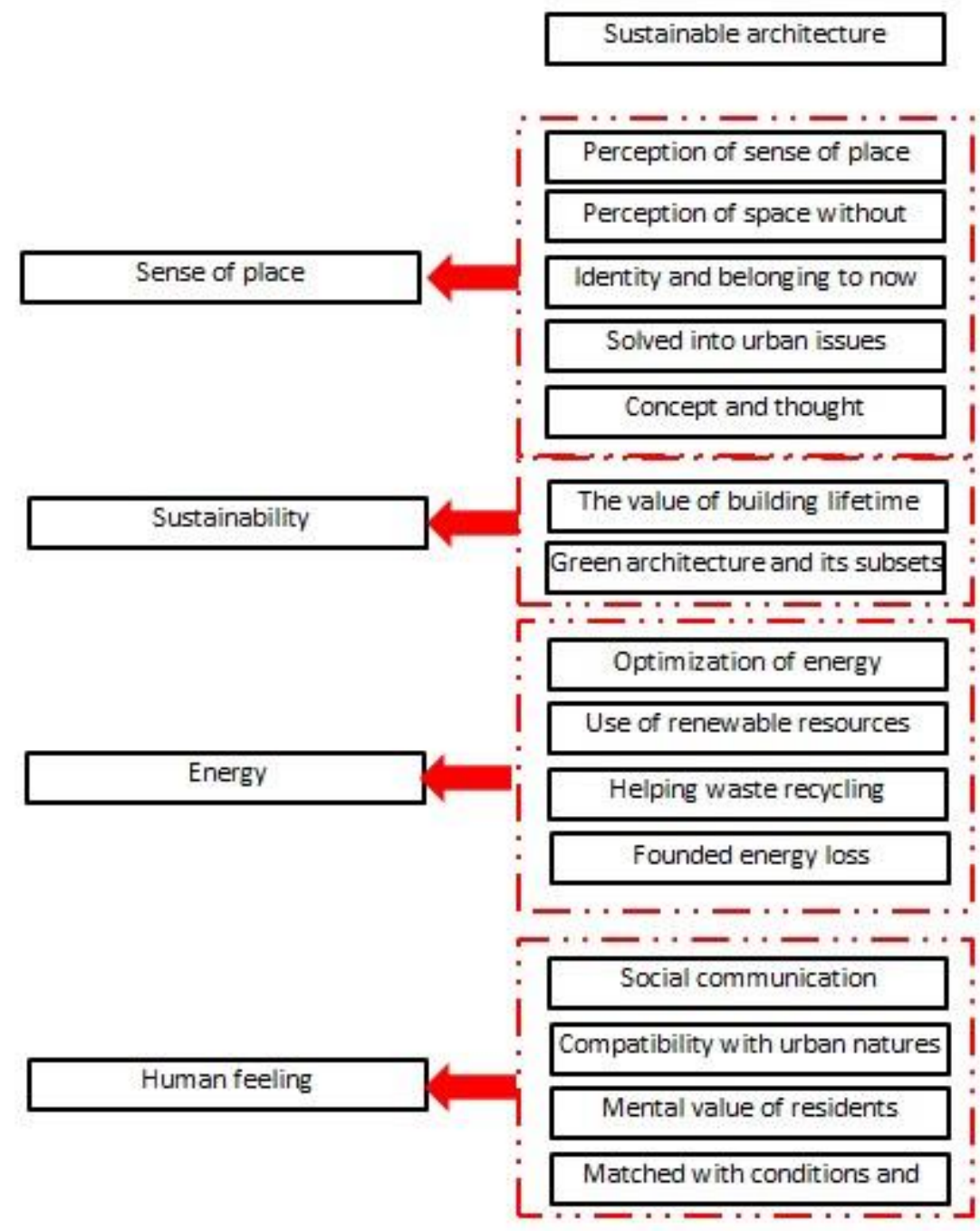

Model2: Relation between sense of place and

15 principles of sustainable architecture.

References: Authors

\section{References}

1. Brinckerhoff, Jackson John (1994)," A Sense of Place, A Sense of Time", Yale University Press, New Haven and London.

2. Canter, D. (1971), "The Psychology of Place", the Architectural Press, London.

3. Golan, G. (1995) "Ethics and Urban Design" New York, John Wiley@Sons 4. Golkar, Korosh (2000), " Sustainable urban design in desert cities", Beauty arts, pp. 43-52, Tehran University Publications, No.8.

5. Gorji Mahlabani, Yusuf, and Yaran, Ali (Spring, 2010), Sterategies of sustainable architecture of City of Gilan compared with Japanese architecture, Pub. Beauty Arts, No. 41 , pp. $45 \& 92$ 
$9^{\text {th }}$ International Conference on Research in Engineering, Science and Technology

France | Paris | April 19-21, 2019

6. Hale, Jonatan A. (2000)," Building Ideas: An Introduction To Architectural Theory", John Wiley \& Sons, Chichester, England.

7. Hosseini, Syad Bagher; Mofidi Shemirani, Syad Majid; Madi, Hossein (2008); "Teaching Sustainable Architecture in Iran, obstacles and trends". Journal of technology and training, No. 3, pp. 213-221

8. Mahmoudi, Mohammad Mahdi (2011), Housing development compatible with sustainable development. Tehran, Pub.Tehran University, p. 4 .

9. Norberg-Schulz, Christan (1975)," Meaning in Western Architecture", Praeger Publishers, New York.

10. Pakzad, Jahanshah (2007)" Principles of traditional urban fabric of Iran", Articles on the contexts of urban architecture and design, p. 69-78, Tehran, Shahidi Publications.

11. Panahi, Siamak (2007), Terminology of sustainable architecture, Etemad newspaper, Khordad 10 (May-June), p.18

12. Panahi, Siamak (2011), Genealogy of energy crisis in ancient Rome, National Conference of City of Ardestan, Islamic Azad University, Ardestan. pp, 3 \& 4.

13. Relph, E. (1976),"Place and Placelessness", Pion, London.

14. Romaldo Giurgola(1998), Louis Kohn, analysis philosophical works, thoughts and viewpoints, translated by Abdolah Jabal Amoli, Khak Publications.

15. Seamon, David (1982)," The Phenomenological Contribution to Environmental Psycology", Journal of environmental psycology, no. 2, pp. 119-140.

16. Seamon, David (1996)," A Pingular Impact", Environmental \& Architectural Phenomenology Newsletter, vol.7, no.3.

17. Sime, Jonathan D. (1986)," Creating Places or Designing Spaces", Journal of Environmental Psychology, no.6, pp. 49-63.

18. Tuan, Yi-Fu (2001), "Space and Place: The Perspective of Experience", University of Minnesota Press, Minneapolis. 